\title{
Arboreal Late Summer Courtship Behaviour of Maritime Garter Snake, Thamnophis sirtalis pallidulus, in Dartmouth, Nova Scotia, Canada
}

\author{
JOHN GILHEN ${ }^{1}$ and Robert STRUM ${ }^{2}$ \\ ${ }^{1}$ Nova Scotia Museum of Natural History, 1747 Summer Street, Halifax, Nova Scotia B3H 3A6 Canada; e-mail: gilhenja \\ @gov.ns.ca \\ 2325 Prince Albert Road, Dartmouth, Halifax County, Nova Scotia B2Y 1N5 Canada
}

Gilhen, John, and Robert Strum. 2007. Arboreal late summer courtship behaviour of Maritime Garter Snake, Thamnophis sirtalis pallidulus, in Dartmouth, Nova Scotia, Canada. Canadian Field-Naturalist 121(2): 210-211.

We report, for the first time, Maritime Garter Snake, Thamnophis sirtalis pallidulus, arboreal, late summer, courtship behaviour in the wild observed 4-5 September 2006.

Key Words: Maritime Garter Snake, Thamnophis sirtalis pallidulus, arboreal, late summer, courtship behaviour, Dartmouth, Nova Scotia, Canada.

On the morning of 5 September 2006 Robert Strum reported to John Gilhen that a ball of snakes had gathered on a Rhododendron shrub, Rhododendron sp., in his yard at 325 Prince Albert Road, Dartmouth, Nova Scotia. In the afternoon of the previous day, 4 September 2006, Robert Strum could see, from the kitchen window, that a number of brown snakes had gathered inside a gazebo style bird feeder on the Rhododendron shrub and he was successful in moving them out. The following morning, 5 September 2006, he noticed the snakes had gathered, again, on a branch near the bird feeder, about two meters above the ground (Cover). Upon investigation it was determined that there were four (three males and one female) Maritime Garter Snakes, Thamnophis sirtalis pallidulus, involved in courtship behaviour: male number 1, the largest male; males 2 and 3 about equal total length; and 1 female (the largest of the four snakes). The weather at 1200 hours on 5 September 2006 was cloudy and overcast with ambient air temperature of $20^{\circ} \mathrm{C}$ and temperature near the ground was also $20^{\circ} \mathrm{C}$.

At 1215 hours the males were observed moving alongside and over the back of the female. At the same time the body of male number 1 was pulsating rhythmically. This male rubbed his chin along the sides of the female. At this time the tail and about one half of the female's posterior trunk (about $20 \mathrm{~cm}$ ) drooped downward from one of the supporting branches, with the tails of all three males wrapped around her tail. While the female's posterior body and tail were dangling down, the most active male (male number 1) appeared to maintain ventral apposition to copulate with her (Figure 1).

All four snakes remained on the Rhododendron shrub from the morning to early afternoon but dispersed at some time late in the afternoon, as they were not seen there again that evening or in the following days. It is not known if copulation occurred over the two-day period these snakes occupied the Rhododendron shrub. One of the two subordinate males was collected as a voucher specimen (NSM55388).
Courtship behaviour of the Maritime Garter Snake in captivity has been previously observed by John Gilhen in late August (unpublished). On two separate occasions (August 2001 and August 2004), days after individual females had given birth, two males were observed following alongside the female and trying to attain cloacal apposition. Although other adult females were present in the enclosure, the males were only interested in courting with a recently spent female. These observations of captives and the present observation in the wild suggests that the Maritime Garter Snake mates in late summer, sometime after females give birth, but prior to hibernation.

Galbraith (2001) reports similar arboreal late summer courtship by Eastern Garter Snakes, Thamnophis sirtalis sirtalis. Cook (1984) mentions snakes in the genus Thamnophis most frequently copulate in spring but have occasionally been noted to copulate in late fall, immediately prior to entering hibernacula. Arboreal spring breeding activity of the Red-sided Garter Snake, Thamnophis sirtalis parietalis, was observed on 8 May 1972 near Inwood, Manitoba (Gregory 1975).

Rossman et al. (1996) and Ernst and Ernst (2003) agree mating of Thamnophis sirtalis usually occurs in spring after emergence from hibernation but may also take place in autumn. Rossman et al. (1996) also states that, until recently, most of the studies of mating behavior and the factors that regulate the timing of reproduction in $T$. sirtalis have focused primarily if not exclusively on spring activities. Previous accounts of the species in Nova Scotia (Barnes et al. 2006; Gilhen 1984, 2000), have not noted fall mating.

The urbanization of both Halifax and Dartmouth cities over the past two decades has been extensive leaving many isolated pockets of amphibians and reptiles. The Maritime Garter Snakes at the observation site in Dartmouth continue to survive in small numbers in a back yard landscape, surrounded by apartment buildings on the south side, a major city road on the north side and other homes on the east and west sides. Galbraith's (2001) observation of the Eastern Garter 


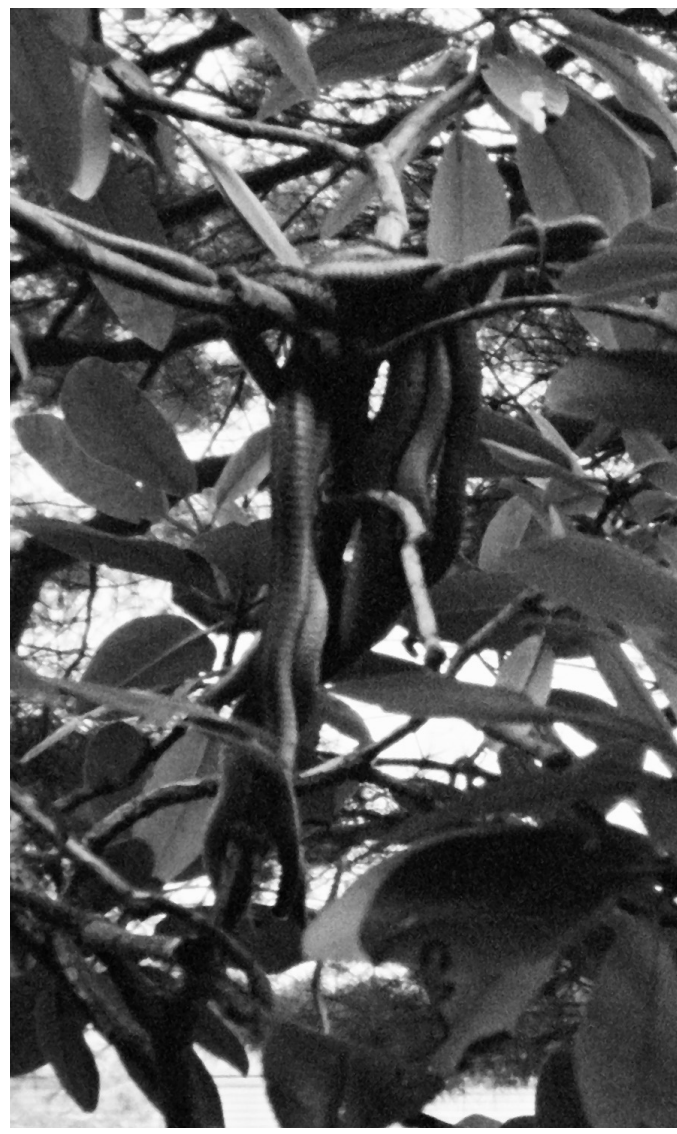

FIGURE 1. An adult male Maritime Garter Snake, Thamnophis sirtalis pallidulus, seeking ventral apposition with adult female in courtship behavior on the branches of a Rhododendron shrub at 325 Prince Albert Road, Dartmouth, Nova Scotia, on 5 September 2006.
Snake also took place on private land in a cottage community on the coast sand dune area of the eastern shore of Lake Huron in Ontario.

In Nova Scotia, the Maritime Garter Snake is most common along the shores of lakes, ponds and streams but has readily adapted to a host of urban habitats. Robert Strum has commonly observed Maritime Garter Snakes in his yard and has noted they move down along the base of the swimming pool and probably hibernate under the pool.

\section{Acknowledgment}

The authors appreciate the advice offered by Andrew Hebda, Curator of Zoology, Nova Scotia Museum of Natural History, during the preparation of the manuscript.

\section{Literature Cited}

Barnes, S., C. M. Dubesky, and T. B. Herman. 2006. Ecology and morphology of Thamnophis sirtalis pallidulus (Maritime Garter Snake) on Georges Island, Nova Scotia. Northeastern Naturalist 13(1): 73-82.

Cook, F. R. 1984. Introduction to Canadian amphibians and reptiles. National Museum of Natural Sciences, Ottawa, Ontario. 200 pages.

Ernst, C. H., and E. M. Ernst. 2003. Snakes of the United States and Canada. Smithsonian Books, Washington and London. 668 pages.

Galbraith, D. A. 2001. Arboreal courtship behaviour by Eastern Garter Snakes, Thamnophis sirtalis sirtalis, in September in Bruce County, Ontario. Canadian Field-Naturalist 115: 347-348.

Gilhen, J. 1984. Amphibians and reptiles of Nova Scotia. Nova Scotia Museum. Halifax. 162 pages.

Gilhen, J. 2000. Amphibians and reptiles of Nova Scotia. Species recorded in the accession books of Harry Piers from 1899 to 1939. Manuscript Report. Nova Scotia Museum of Natural History.

Gregory, P. T. 1975 . Arboreal mating behaviour in the Redsided Garter Snake. Canadian Field-Naturalist 89: 461-462.

Rossman, D. A., N. B. Ford, and R. A. Seigel. 1996. The garter snakes: Evolution and ecology. University of Oklahoma Press, Norman, Oklahoma.

Received 2 November 2006

Accepted 11 March 2008 